philosophical chair in his native town, where he exhibited all the high qualities of bis exalted intellect.

It is equally well known that he interested himself all his life in our scientific and literary institutions as well as the intellectual and material development of our ancient Republic. Many of his writings, unknown doubtless elsewhere, were received here, and the Society for the Advancement of Art founded by him still continues a work to which he was devoted.

Even when this monument to his memory shall have been raised on foreign soil, Geneva will show its gratitude towards those who have taken the initiative in this demonstration, and will honour those who take part in it.

It is with this firm assurance that the Committee at Geneva is formed to collect subscriptions.

The inauguration of the memorial is projected for the $3 \mathrm{rd}$ of August, 1887, that being the centenary of H. B. de Saussure's ascent of Mont Blanc. There is therefore no time to be lost that it may be finished by that date. It is important that the Initiative Committee at Chamounix should know as soon as possible the sum they have at their disposal, in order to decide what form the monument should take.

6, Rue des Granges, Geneva, 20 th December, 1885 .

Alphonse Favre,

President of the Swiss Geological Commission.

\title{
A MONUMENT FOR PROFESSOR OSWALD HEER OF ZURICH.
}

Sir,-Two years have passed since Death carried off one of the most eminent naturalists of our age-Oswald Heer. He died on the 27th of September, 1883. 'The fitting moment seems to have arisen to render Dr. Heer a public acknowledgment and to raise a lasting monument to his memory. We are glad to be able to inform you that a sculptor of Zurich, M. Hörbst, has modelled a bust in clay, which gives the naturalist's expression in the most pleasing manner.

The work of Heer was wide-spread. Although truly Swiss at heart, and studying with delight the primitive history and flora of his native land, his researches extended far beyond the limits of his own country. He had become one of the highest authorities on the domain of vegetable palæontology, and from all parts of the world, from the islands of Sunda and from "hyperborean" lands, from Portugal and Eastern Siberia, from the New World as well as the Old, he gathered materials for his researches, and specimens came for identification. The works of Heer on the fossil flora of the Polar regions have placed him among the foremost ranks as one of the founders of modern botanical geography; for to him, and him alone, is due the merit of having discovered, by studying the marvellous Tertiary flora of Greenland, Spitzbergen, and Arctic America, facts of the utmost importance to science. His name will perpetually remain united with those who have explored Arctic regions, his researches will long form the basis of our knowledge of prehistoric climates.

'Feeling assured of the eminently international character of Heer's 
work, we confidently appeal to all to raise a worthy monument to his memory.

It is proposed that this monument should consist of a marble bust on a stone pedestal, protected in a suitable manner from the inclemencies of the weather, to be placed in the Botanical Gardens at Zurich, on the spot where Heer's energy was so well displayed. 'The price of the memorial would reach about 5000 francs.

Besides which, the sculptor, M. Hörbst, is prepared to execute, for 150 francs each, plaster casts of the original. If you desire one of these copies, have the goodness to inform us, when sending your contribution. Subscriptions will be gratefully received by Dr. C. Schröter at Hottingen, Zurich. They may be sent direct, or through the medium of the undersigned.

Prof. Dr. A. Mousson, Polytechnikum, Zurich.

Prof. Dr. C. Cramer, ,

\section{OBITUARY.}

\section{PROFESSOR A. VON LASAULX PH.D.}

$W$ deeply regret to have received tidings of the death of this distinguished German Geologist and Mineralogist, which took place at Bonn, on the 25th January last, after a short illness. Dr. Von Lasaulx was only in his 47th year; yet he had been the autbor of a remarkably large number of Memoirs on petrological subjects, as well as of more solid works, of which, perhaps, the joint work on Etna of Sartorius von Waltershausen and himself is the most splendid example. In 1876 Dr. von Lasaulx, in company with his friend Dr. Ferdinand Roemer, of Breslau, visited the British Isles; and was present at the meeting of the British Association in Glasgow in that year. On his return to Bonn, he published an account of his wanderings, in the form of a handsome hook, "Aus Irland, Reiseskizzen und Studien," in which the physical features and geological structure of the districts visited are closely noted and graphically described, together with the mineral characters and composition of many of the rocks as determined under the microscope; of these, the most important was the discovery of tridymite in the trachytic rocks of Antrim (Petrographische skizze aus Irland; mineralogischen und petrographischen Mittheilungen, Wien, 1878, p. 410). The volcanic rocks of Bonn and the neighbourhood afforded a rich field for the petrological investigations of this lamented naturalist, of which he made abundant use.

E. H.

We regret to record the death (on the 16th February, from heartdisease) of Mr. W. W. Leighton, who, since the year 1867, has filled the office of Clerk to the Geological Society of London, and has during 19 years been a most faithful and valued servant to the Society. 